\title{
THE IMPACT OF COVID-19 PANDEMIC ON THE REAL ESTATE MARKET DEVELOPMENT PROJECTS
}

\author{
Marina Jovanović-Milenković, Ana Đurković, Darko Vučetić, Borko Drašković
}

\begin{abstract}
Republic Geodetic Authority, Belgrade, Serbia
\end{abstract}

Received: 5 June 2020

Revised: 15 June 2020

Accepted: 22 June 2020

\begin{abstract}
During the Covid-19 pandemic, there were changes in the way businesses operate around the world. Market participants have focused their business on business by applying egovernment services. The impact of Covid-19 was also felt in the real estate market development projects. The paper gives a parallel overview of the real estate market in China, the USA and Europe. An overview of data from the real estate market in Serbia is given on the basis of data from the Republic Geodetic Authority. Regardless of the fact that the virus pandemic appeared in different time periods in the world, it can be concluded that the indicators of changes in the real estate market indicate the same trend of the behaviour of the indicators.
\end{abstract}

Keywords: Real estate market development projects, Covid-19, e-government services, Republic Geodetic Authority.

\section{INTRODUCTION}

The advent of Covid-19 has brought major changes to all business segments globally. The health condition of the population is endangered, there has been a large occurrence of mortality, which is why many countries have introduced precautionary measures. According to statistics from May 2020, over 5.8 million people in over 200 countries have been infected with this virus (Gis and data, 2020).

The existence of Covid-19 has not only led to changes in the health care system, its impact has also led to changes in the global economy. The consequences of the recession from ten years ago, which caused high unemployment, are still being felt in the economy, and with the current change of business, the economic crisis is deepening. The world is experiencing a decline in stock prices and a decline in oil prices. Industrial production has declined, and the services market is recording a decline in profits (McKibbin, \& Roshen, 2020). There was a closure of organizations, job losses, and even a change in lifestyle. The population has reduced its movements to a minimum, by going less to commercial and public buildings, and the importance of the rural household is increasingly understood.

The question is: what is the impact of Covid19 on the real estate market development projects?

\section{REAL ESTATE MARKET DEVELOPMENT PROJECT}

The real estate market development project is a significant component of a country's economy. It is vital to the global economy as a source of investment and as a driver of growth and job creation. Financial liquidity and availability of funds are essential for the health of the real estate market (Pagourtzi, Assimakopoulos, Hatzichristos, \& French, 2003).

However, the real estate market is an extremely complex concept characterized by unpredictability. This fact is primarily conditioned by the following factors: political and economic (Djokovic, 2009). Given these

Corresponding author. Email: marina.milenkovic@ rgz.gov.rs

ISSN 2560-4961 (online)

Copyright $\mathbb{C}$ 2020, The Authors. Published by IPMA Serbia.

This is an open access article under the CC BY-NC 4.0 license (https://creativecommons.org/licenses/bync/4.0/)

doi: $10.18485 /$ epmj.2020.10.1.5 
factors, the real estate market has recently progressed sharply in both size and complexity.

The impact of Covid-19 on the real estate market development project has certainly changed. The real estate market is governed by the law of supply and demand. Due to the threat to the lives of residents and the impossibility of free movement of the population, at this moment in the world there is a decrease in demand for real estate. The population primarily turns to satisfying their existential needs and preserving their health.

\subsection{The Real Estate Market Challenge}

The real estate market development projects ensured its survival during the virus pandemic by applying new technologies. There was an application of electronic business, the transition to the digital and virtual world. The Covid-19 pandemic has transformed the market, adapted it and applied it to new ways of doing business (Bethune, \& Korinek, 2020).

In order to maintain the economy, all market participants applied e-government services. Egovernment is a term that represents the concept of e-business of the government and refers to the delivery of electronic services to various target groups in the public, and to business cooperation and transactions that the government performs with various organizational entities (Jovanović-Milenković, Radojičić, Milenković, \& Vukmirović, 2009; Keramati, Behmanesh, \& Noori, 2018). Therefore, the essence of the new way of functioning of public administration is electronic business, i.e. its direct application (Radenković, Despotović-Zrakić, Bogdanović, Barać, Labus, \& Bojović, 2017). It achieves goals such as reducing administrative costs, improving transparency and predictability of the business environment, simplifying administrative procedures, optimizing time spent, and improving the quality of public administration services (Caldwell, Baum, \& Di Maio, 2000; Naled, 2019). Technology is not just a basis of e-commerce for quite some time; nowadays it is turning the industry into what could be the foundation of modern retail business (Tahirović, Naumović, Živojinović, Bogdanović, \& Despotović-Zrakić, 2018).
The transition to the digital and virtual world has now proved more important than ever. Currently, due to the market situation, agents had to be more creative than they ever were, in order for their results to remain relevant. Many have tried to have more virtual presence, 3D tours, virtual presentations. Some banks in the world have started conducting real estate appraisals based on virtual tours and images that have already been posted on the sites of real estate associations.

Applying virtual tours in business is probably an effective way to help buyers experience real estate. Such tours are published on social networks, as another new tool for possible real estate sales (Forbes, 2020).

The author Lisi G. stated, in her work from 2019, that for future research of the real estate market it is interesting to follow the process of real estate search and harmonization with price growth on the "online search" model (Lisi, 2019). Such a possibility now appears in the world, where all real estate transactions take place through e-government services. Given this, the new virtual reality of the real estate market development project is likely to have a long-term impact on future business, as health security is currently required (Pickford, 2020).

\section{THE TREND OF SALES IN THE REAL ESTATE MARKET DURING COVID- 19 IN THE WORLD}

During the Covid-19 pandemic in the world, the real estate market sustained changes. There was an impact on real estate transactions. In the next part of the paper, we can see how real estate markets developed on certain continents during the duration of Covid-19.

\subsection{Real Estate Market Development Project in China}

The Chinese market has accepted the challenge of transferring the real estate market to the virtual world (Gross, \& Lin, 2020). Numerous applications show real estate with adequate description and search functions with simple selection criteria, such as location, price and unit type, realistic virtual experiences. It's a system that updates in real time how many potential buyers have viewed the property, including mortgage services. 
However, despite all efforts to sustain the market, there has been a drop in sales according to China Merchants Securities (China Merchants Securities, 2020). The appearance of Covid-19 led to a drop in real estate sales by $70 \%$ compared to the same period in 2019. The following chart shows that the decline in real estate turnover in January 2020 fell by $69 \%$ compared to the same period in 2019, while in February there was a decline of 58\% (Figure 1) (Pere, 2020).

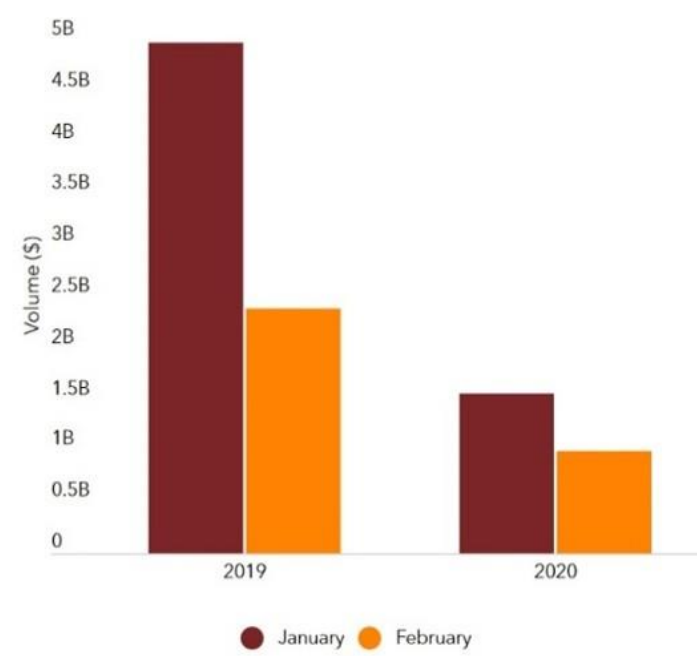

Figure 1: Parallel insight into real estate sales in China in the same period during 2019 and 2020 (Real Capital Analytics, 2020)

The Chinese State Bureau of Statistics announced that the prices of newly built apartments increased by only $0.27 \%$ during December and January in 70 large cities. This growth is extremely small compared to the growth in the last two years (National Bureau of Statistics of China, 2020).

\subsection{US Real Estate Market Development Project}

Before the coronavirus pandemic hit the United States, the residential real estate market development project was in a stable position. Although there was a smaller supply of houses for sale, there was too much demand in the market. In particular, the low interest rate environment that has prevailed since last summer has maintained increased sales volumes.

However, with the appearance of the virus on the US market, there has also been a decrease in real estate sales, according to the National Association of Realtors (National Association of Realtors, 2020). In the last week of March, the number of properties for sale fell by $13.1 \%$ and $34 \%$, respectively, compared to the same period a year ago. The pace of real estate price growth slowed during the second half of March. Many real estate sellers withdrew their properties from the list of sales, because they did not want to sell at low prices. Newly listed real estate in April 2020 decreased by $44.1 \%$ compared to last year (Norada Real Estate Investments, 2020).

According to the National Association of Realtors (National Association of Realtors, 2020), the average price of apartments in March 2020 was 8\% higher than in March 2019. However, updated data for real estate market forecasts (National Association of Realtors, 2020) show that house sales will decline by $15 \%$ in 2020 . Such a conclusion was formed based on the opinions of potential buyers where $43 \%$ of them postponed the purchase for several months, $20 \%$ gave up the purchase due to job loss and concerns about further work, $12 \%$ continued further search for real estate, and the rest gave up further purchases.

Capital Economics estimates that four million properties will be sold in 2020, which is the lowest since 1991. To compare this data, the authors state that 5.3 million properties were sold in 2019. Based on that, it is predicted that in 2021, about six million will be sold instead of 6.3 as was predicted before the virus pandemic (Figure 2). 


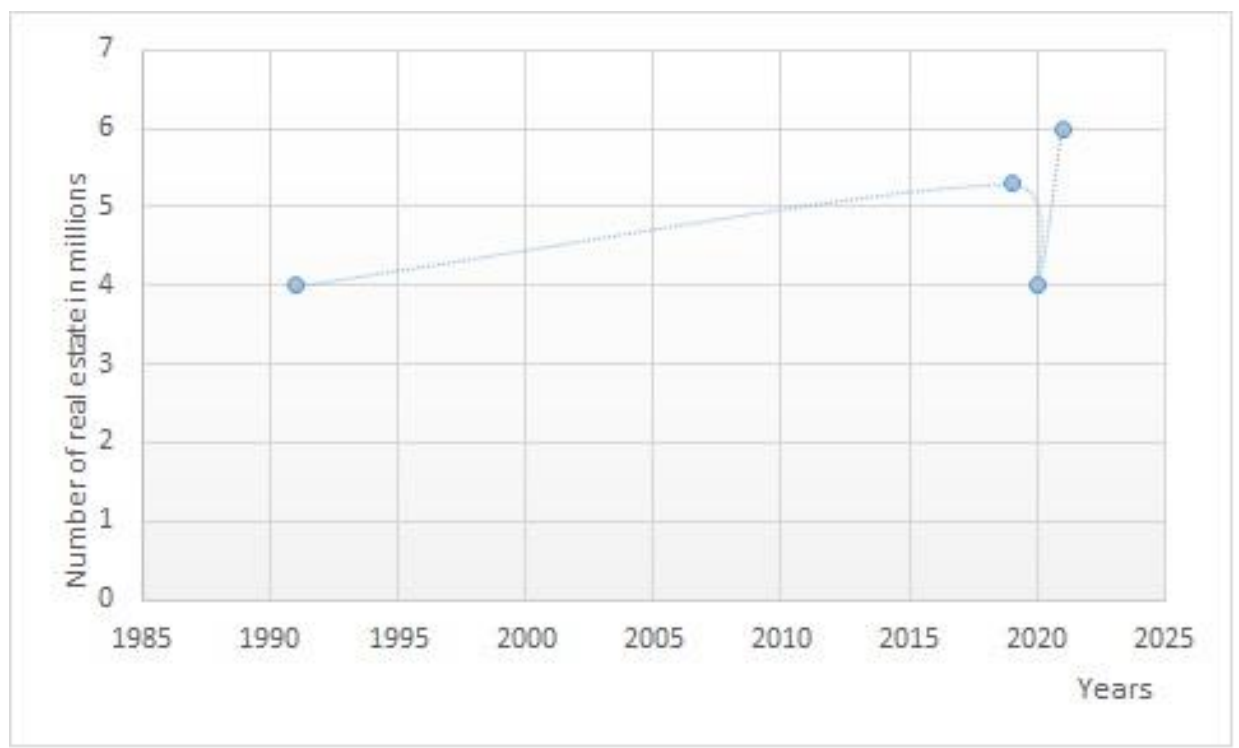

Figure 2: Trend in real estate sales

Mason \& Morse's Wells envisions a shift in customer priorities regarding where and how they want to live in the U.S. and beyond. According to a survey from April, conducted by the real estate association Realtor (National Association of Realtors, 2020), it concludes that citizens have expressed greater preferences for real estate that has a suitable yard. Such buyers are interested in real estate in suburbs near big cities, because they understand the importance of free movement.

\subsection{European Real Estate Market Development Project}

The European real estate market has almost stopped, with an increase in Covid-19 patients. In this part, the real estate market in Great Britain, Italy and the Republic of Serbia is analysed.

\subsubsection{The UK Real Estate Market Development Project}

The UK real estate website reported that customer demand fell by $40 \%$ during the week that ended on March 22 compared to the previous seven days. In May, the real estate market opened in England, while it remained closed in Wales, Scotland and Northern Ireland. Visiting houses in the standard way is still not allowed according to the regulations introduced due to Covid-19. What is certain is that the real estate portal has seen an increase in turnover of up to a fifth, which indicates that the state of the real estate market is returning to the level before the virus appeared.

Zoopla's web portal estimates that the sale of about 373,000 properties worth about 82 billion pounds has been stopped. The figure 3 gives a parallel overview of real estate sales in the same period during 2019 and 2020, where it can be seen that March 23 is the date when sales start to decline sharply.

According to their research, the demand of real estate buyers has decreased by $70 \%$ in a few weeks, and real estate rentals have decreased by $42 \%$ since the beginning of March (Zoopla Estimates, 2020). 


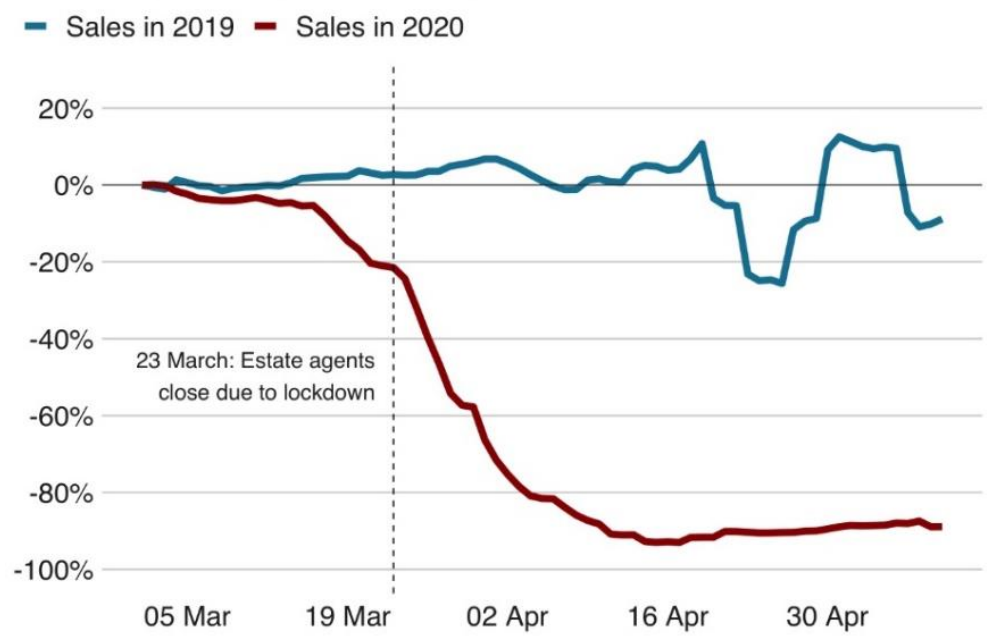

Figure 3: Real estate sales during 2019 and 2020 in the UK (Zoopla Estimates, 2020)

\subsubsection{Real Estate Market Development Project in Italy}

The research company Nomisma, based in Bologna, Italy, concluded that the situation on the Italian real estate market is undoubtedly very serious, with a drop in turnover compared to the previous year. Turnover fell by anywhere from 9 billion to 22 billion euros compared to the first quarter of 2020. Their estimates suggest that it will take three years for the real estate market in the country to recover, creating a total loss of 122 billion euros (Nomisma si trova a Bologna, 2020).

\subsection{Real Estate Market Development Project in the Republic of Serbia}

The global economic situation is similar in the territory of the Republic of Serbia. Considering that, during the state of emergency in the territory of Serbia, the recommendation to stay at home and to respect the adequate social distance was valid, modern technologies were applied when buying and selling real estate. Namely, an innovative approach to visiting properties was used. Virtual tours are organized, which include the display of real estate in $360^{\circ}$ technology, viewing of real estate through video with interactive plans in order for the buyer to gain a realistic insight into the equipment, design and layout of the premises.

Considering that the Republic of Serbia has been working on the digital transformation of all business processes in recent years, the
Republic Geodetic Authority (RGA) has contributed to the successful establishment of the e-front desk as a new system of certification and registration of documents related to the business application process, and delivery of documents for registration in the real estate cadastre and utilities cadastre.

This method automates part of the activity, increases the efficiency in processing requests and reduces the need for a traditional visit to real estate cadastre services. The full significance of the e-front desk was realized during the registration of real estate during the duration of Covid-19, because the necessary communication with the cadastre services took place electronically.

Also, the Republic Geodetic Authority, as a special step in the development of the system of mass real estate valuation, and with the support of the World Bank, established the system of the Real Estate Price Registry, as a record of realized transactions on the real estate market. The Real Estate Price Registry system supports the development of the real estate market by enabling some of the main concepts of the real estate market, such as transparency, efficiency and maturity of the market, and allows sales data to be available to professional users and stakeholders.

Through the Real Estate Price Register, data on the real estate market is collected and processed. This achieves the quality of information, using a known procedure and methodology for mass valuation of real estate. 
This system provides a starting point for all real estate market analysis and asset valuation.

In order to have a true picture of the impact of Covid -19 on the real estate market in the Republic of Serbia in the period of the declared state of emergency from 16.03.-07.05.2020, data on the real estate market available to the Republic Geodetic Authority, ie. authoritative turnover data from the Real Estate Appraisal and Management Department, is of great importance. Due to future guidelines in the real estate market, several indicators were monitored:

- Number of realized sales;

- Method of payment for executed transactions;

- Average price;

- Realized turnover of real estate by type of real estate;

- Share of participants in the real estate market.

\subsubsection{Number of Realized Sales}

The first indicator of the real estate market in the Republic of Serbia is the number of realized sales. For this analysis, two periods during 2019 and 2020 were considered:
- From January 1 to March 15, 2019, ie. 2020;

- From March 16 to May 7, 2019, ie. 2020.

An analysis of the total number of sales contracts in the first quarter of 2019 and 2020 shows that the number of sales during 2020 was higher by $12 \%$ compared to 2019 . There was an assumption that such a trend would continue in 2020, because the last Report on the movement of the real estate market in 2019 promised a golden spring and record amounts of money on the real estate market. Mostly low interest rates on housing loans, changes in the law and encouragement of legal construction contributed to that. However, during the state of emergency, the number of sales contracts fell. Compared to the same period last year, it decreased by $70 \%$ (Republic Geodetic Authority, 2020).

The following figure shows data on the number of sales contracts for the administrative centers of Belgrade, Novi Sad, Nis and Kragujevac, as well as for the entire territory of the Republic of Serbia.

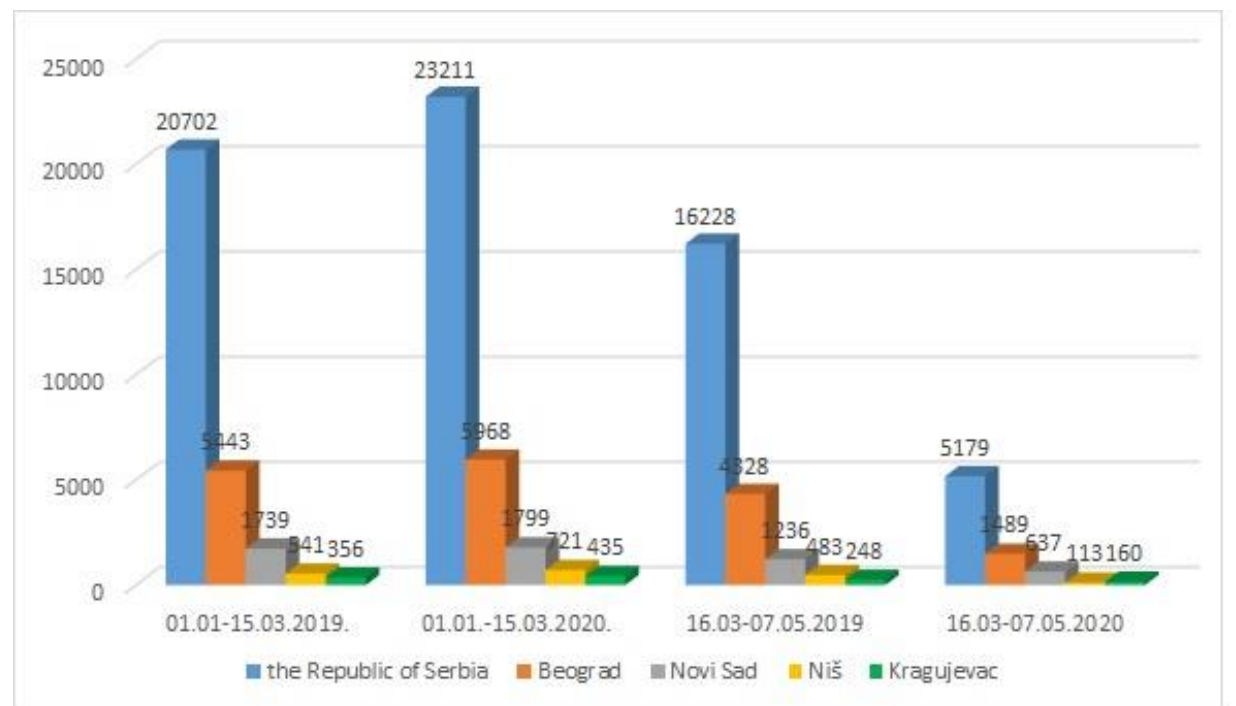

Figure 4: Total number of sales contracts in the Republic of Serbia in the first half of 2019 and 2020

The following figure compares the number of contracts received from notaries based on the date of contract verification. The period from March 16 to May 7 during 2019 and 2020 was analyzed. The figure shows that the number of contracts is declining in March, a constant value is maintained in April, and in May that number will start to grow. 


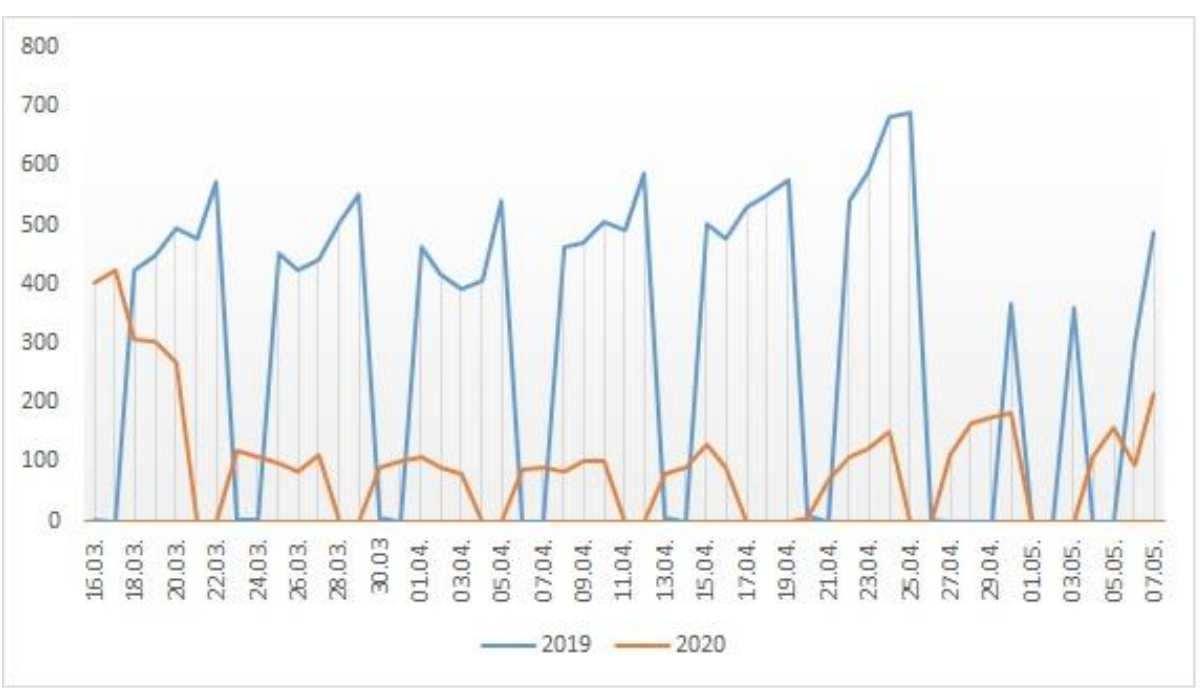

Figure 5: Number of received contracts from notaries public by the date of contract verification during 2019 and 2020

Focusing only on the period of the state of emergency and the number of received sales contracts in the real estate price register system, and highlighting the administrative centers in the Republic of Serbia, it can be seen that the situation has changed by weeks. For the first few weeks, the number of contracts went down. For almost the entire month of April, the number of contracts kept a constant value, only to start growing at the end of the state of emergency. Considering the administrative centers, most contracts were realized on the territory of Belgrade (Figure 6).

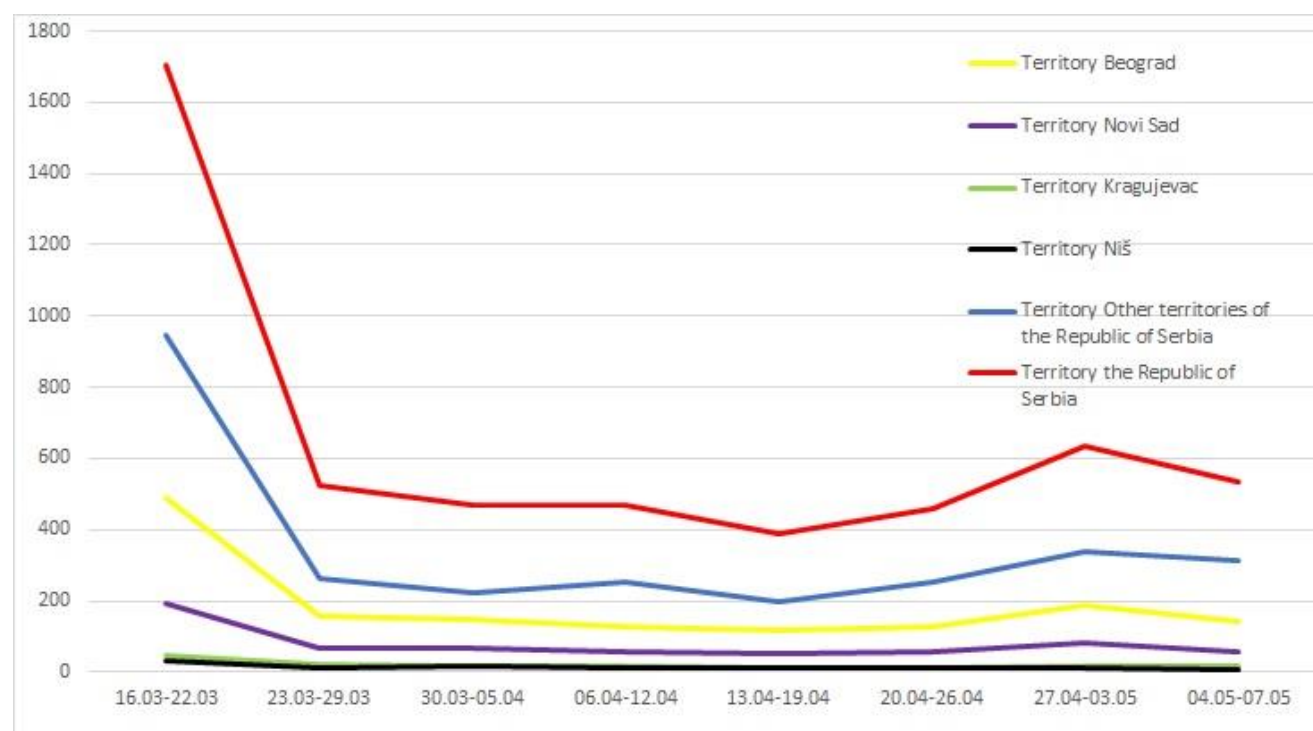

Figure 6: Number of contracts during the state of emergency in the Republic of Serbia

However, it is interesting to note that the recovery of the real estate market was visible in the first week after the end of the state of emergency with a tendency of constant growth (Figure 7). 


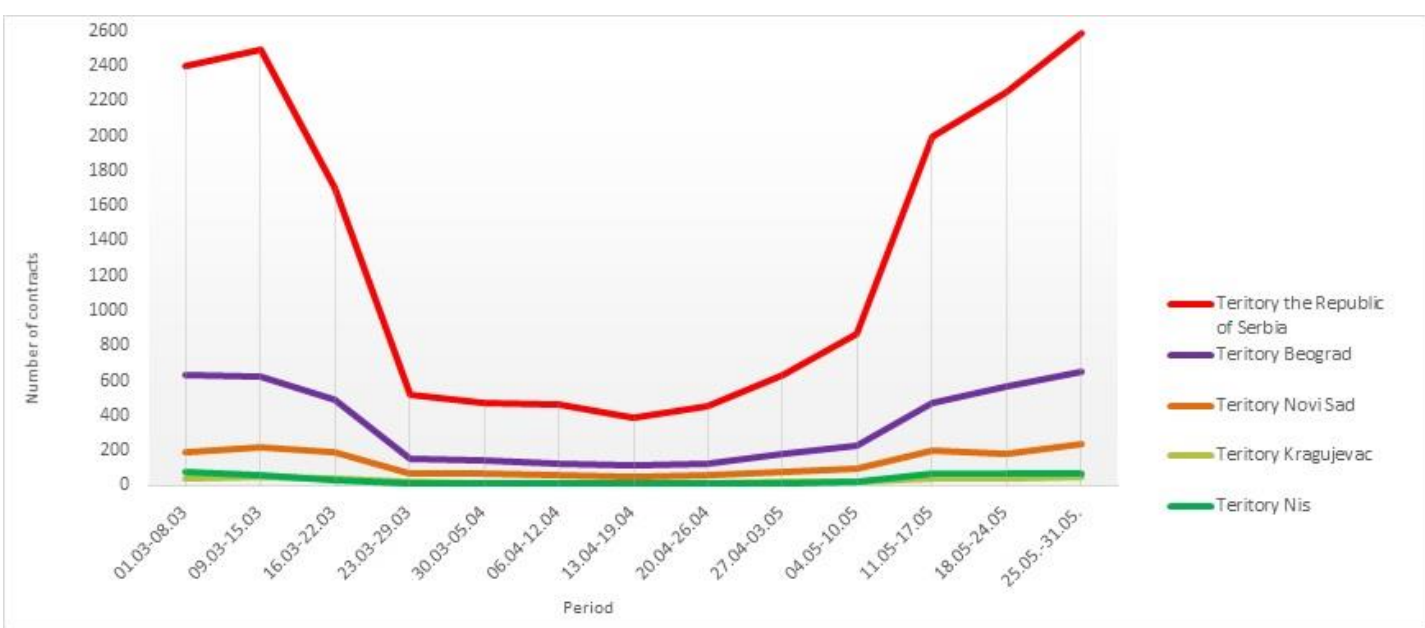

Figure 7: Number of contracts after the end of the state of emergency in the Republic of Serbia

3.4.2. Method of Payment for Executed Transactions

According to the method of payment for executed transactions, the real estate market reacted considerably during the state of emergency. Data was processed on a daily basis by type of real estate in circulation, where in total it can be seen that the number of executed transactions in cash was $67 \%$ in relation to the number of executed transactions from credit borrowing. The following figure shows transactions by week based on the method of payment during the state of emergency (Republic Geodetic Authority, 2020).

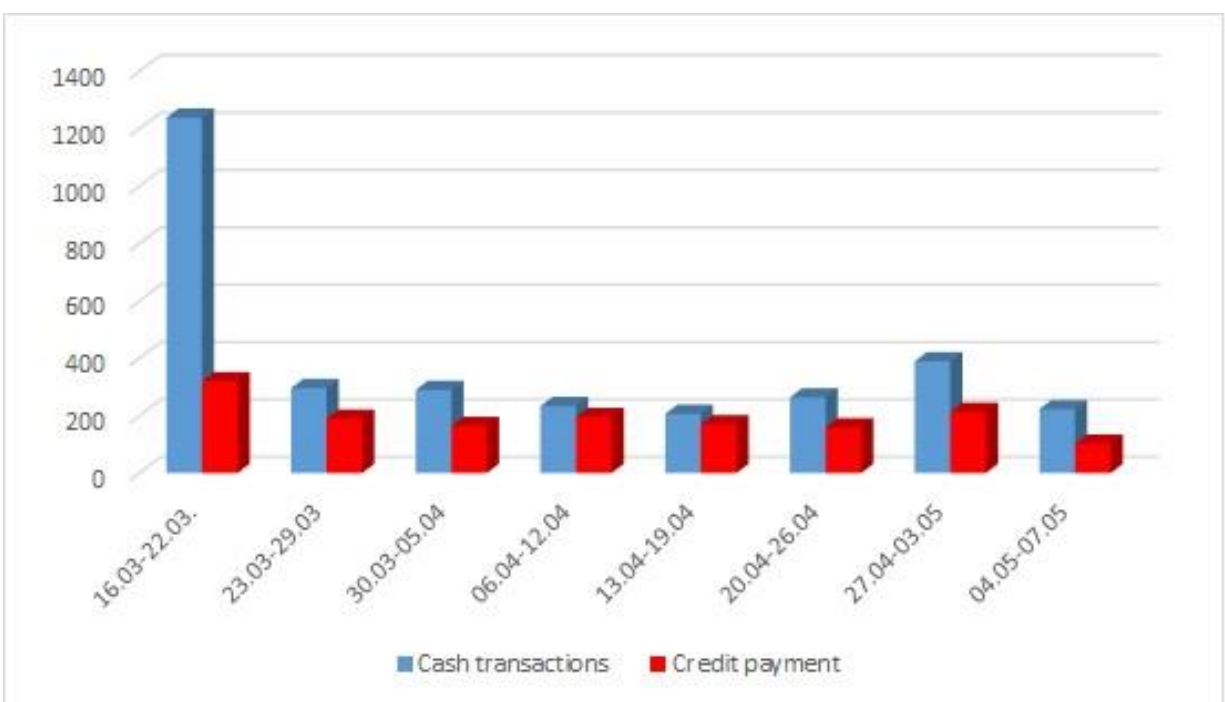

Figure 8: Overview of the method of payment during the state of emergency in the Republic of Serbia

With the end of the state of emergency, the structure of the method of payment changed. The ratio of cash and credit transactions came to the same level in the first three weeks as before the introduction of the state of emergency (Figure 9). 


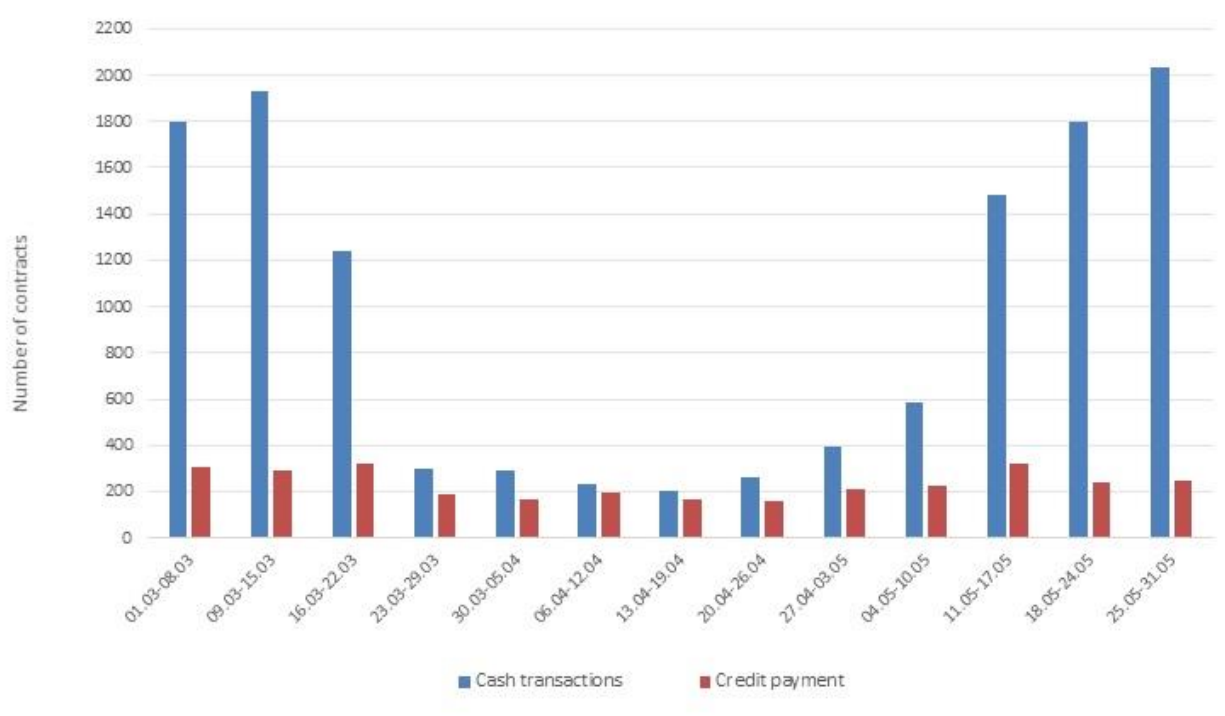

Figure 9: Overview of the method of payment after the end of the state of emergency in the Republic of Serbia

If we compare the period of the state of transactions was $67 \%$, ie. $88 \%$, and in the share emergency with the same period from 2019, it in the credit payment 33\%, ie. 12\% (Figure 10) can be noticed that the share of cash (Republic Geodetic Authority, 2020)

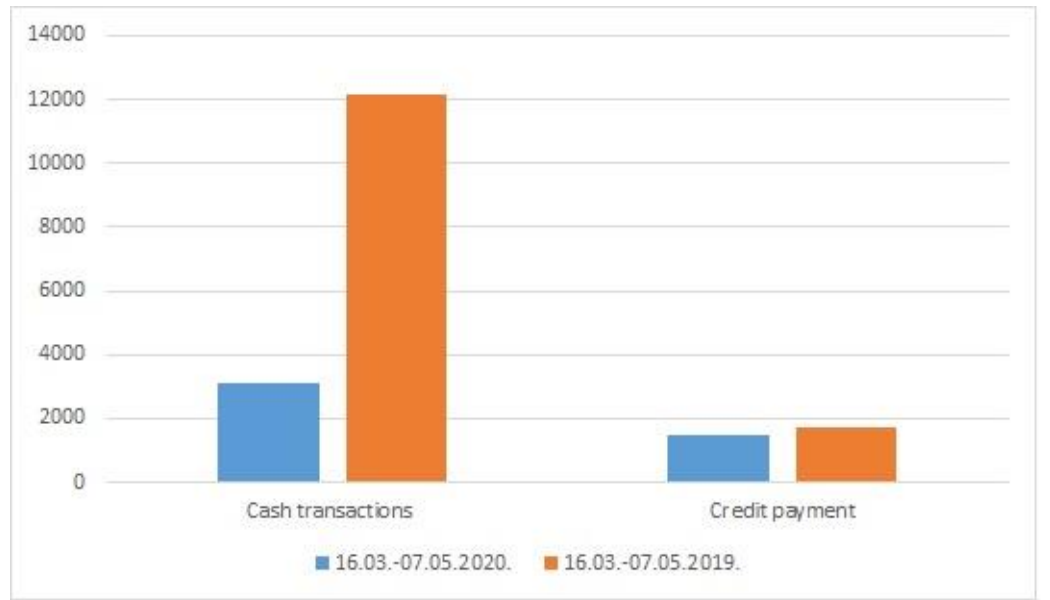

Figure 10: Presentation of payment methods for the same period during 2019 and 2020

If we single out only apartments in the period of emergency, the share of cash payments and credit borrowing is almost equal, while for the same period in 2019 this ratio was $73 \%$ of cash transactions versus $27 \%$ of transactions within credit borrowing (Republic Geodetic Authority, 2020 ).

\subsubsection{Average Price}

In order to see the relationship between supply and demand for real estate, one of the important indicators is the average price of real estate. Average real estate prices in Belgrade and in larger administrative centers were analyzed. There are two trends of price changes. The average price of real estate in different municipalities in Belgrade behaved differently.

The first trend refers to the price of old real estate in euros per $\mathrm{m}^{2}$, where there is an increase in prices compared to the price at the beginning of the year, on average about $4 \%$ (with the exception of the city municipality of Savski venac where the price jumped by almost 
$20 \%$ and the city municipalities of Zvezdara and Vracar where there was a slight drop in prices). The second trend refers to the real estate prices of new construction, where we have different individual situations where the data are not homogeneous. The largest part of the sold apartments in the new building consists of housing units within the housing complexes, which also affected the price of apartments in traffic in an emergency condition. The following figure shows the average real estate prices in the municipalities of Belgrade (Republic Geodetic Authority, 2020).

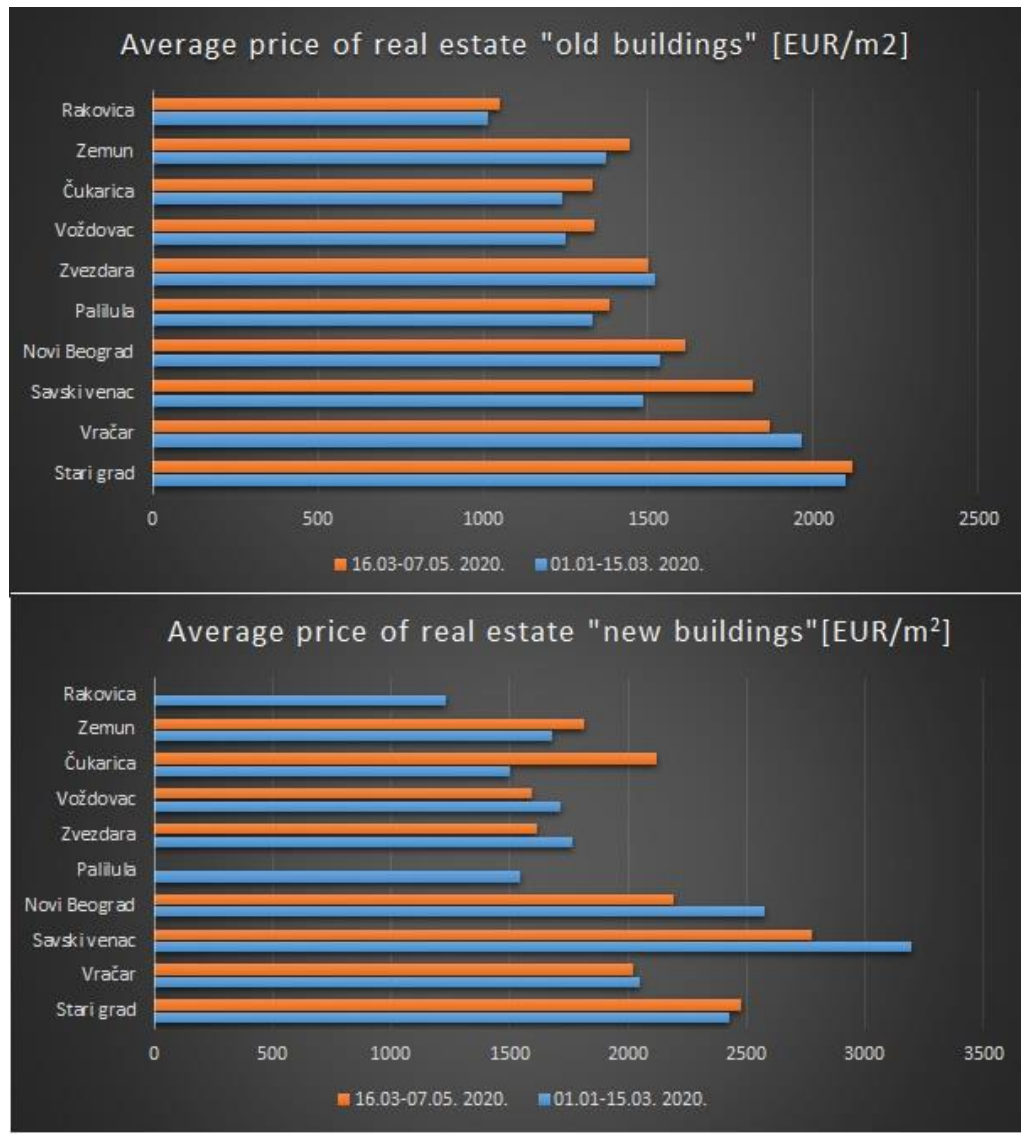

Figure 11: Average prices of old and new buildings in Belgrade municipalities

Analysis of real estate price data in cities in Serbia shows that the price of apartments has maintained the same level. There have been slight fluctuations in real estate prices to more when it comes to "old construction". The following graphs show the prices of old and new buildings in cities in Serbia (Figures 12 and 13).

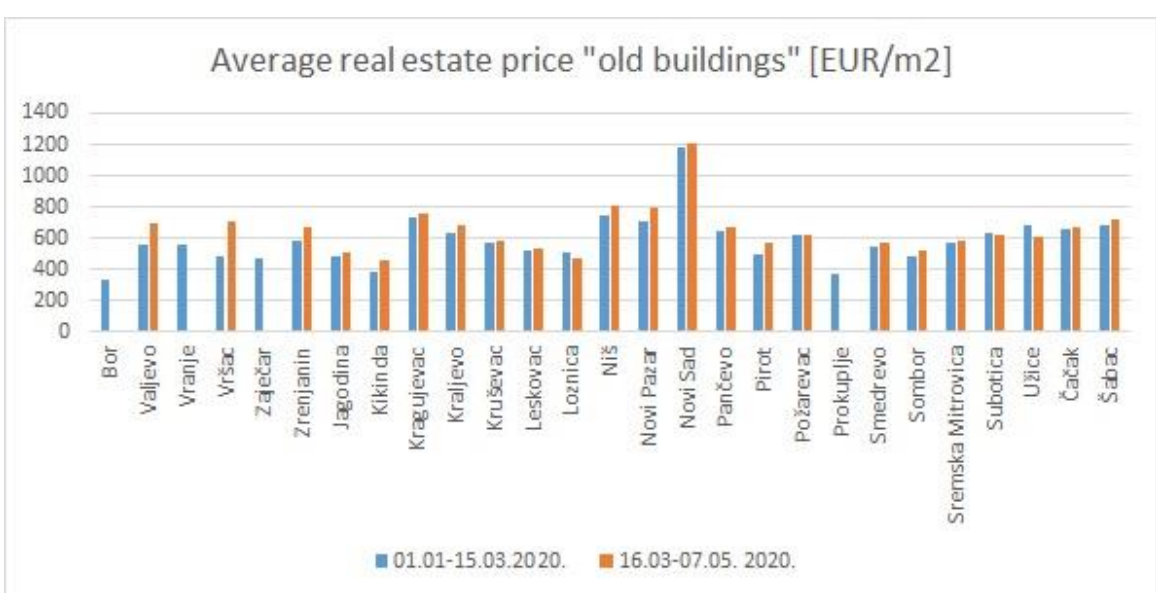

Figure 12: Average price of old buildings in cities in Serbia 


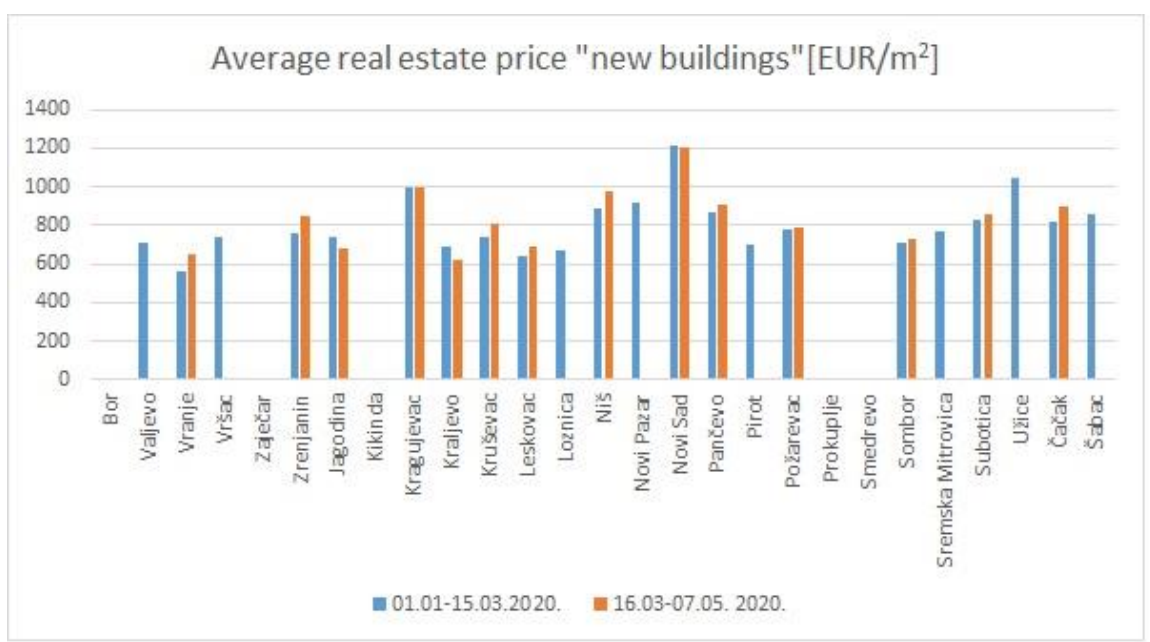

Figure 13: Average price of new real estate in cities in Serbia

Also, the parameters of the average price of agricultural land in the region of Vojvodina in the period from March to May 2019 and 2020 were considered. Comparing the prices, it can be seen that the price of land increased in 2020 . Agricultural land prices are shown in the following figure 14 .
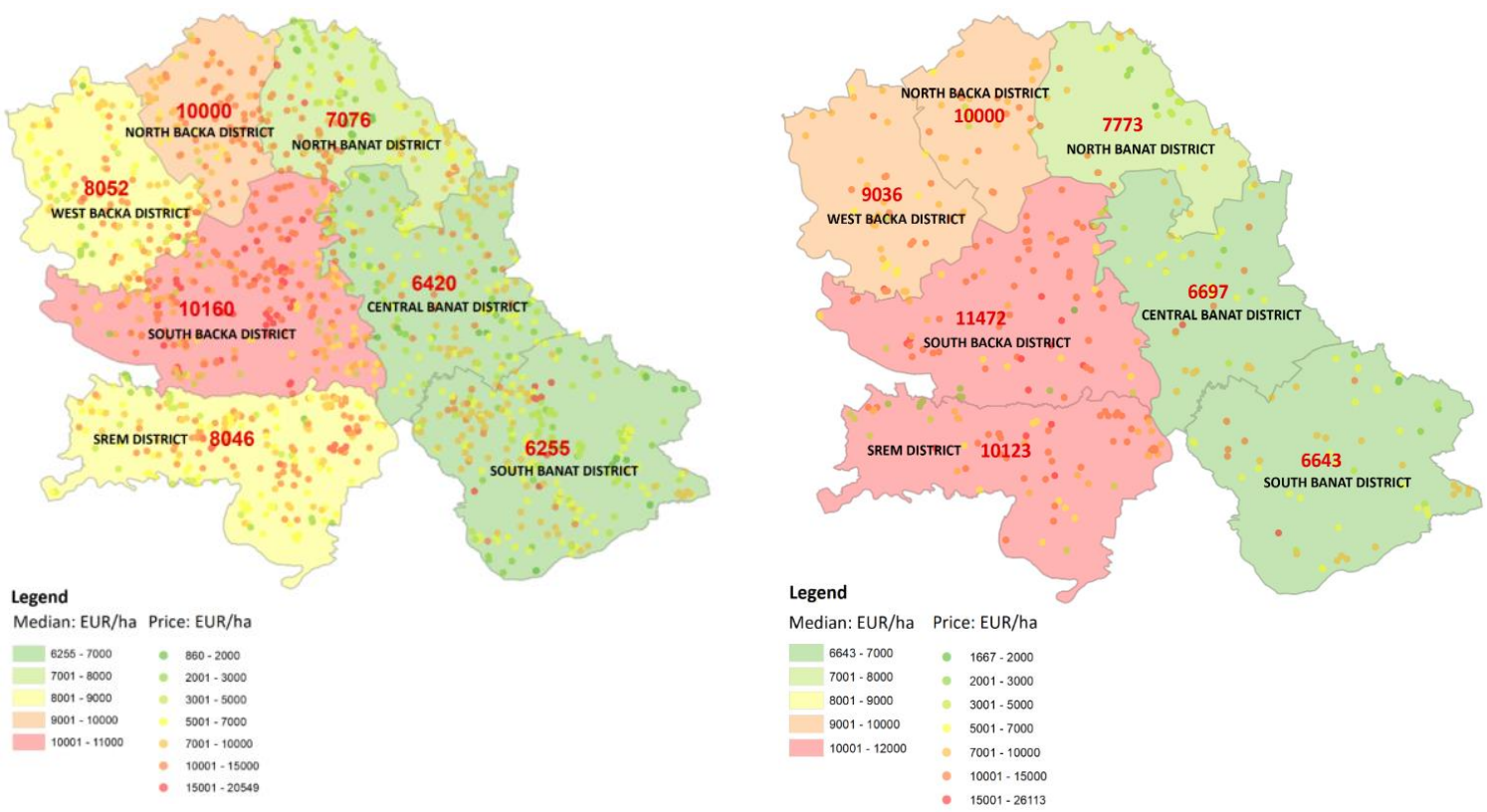

Figure 14: Average prices of agricultural land in the region of Vojvodina in the period from March to May 2019 and 2020 (Republic Geodetic Authority, 2020)

When drawing conclusions regarding the average prices in the state of emergency, special care had to be taken due to the much smaller set of data from the state of emergency in relation to the set of data with which it is compared.

Expectations for the next period regarding real estate prices are difficult to predict. Given that the volume of the market has returned to the level it was at before the introduction of the state of emergency, it is realistic to expect that prices will remain at the level from the beginning of the year, in the next few months. After that, the real estate market will be determined by the current socio-economic factors in the Republic of Serbia. 


\subsubsection{Realized Real Estate Turnover by Type of Real Estate}

Real estate type is an indicator that provides information on which type of real estate was sold the most in the observed period. A parallel was drawn between the period before the state of emergency and during the state of emergency during 2020, and the following conclusions were reached. During the state of emergency, more apartments and garage space were sold, and less agricultural and construction land compared to the previous period (Figure 15).

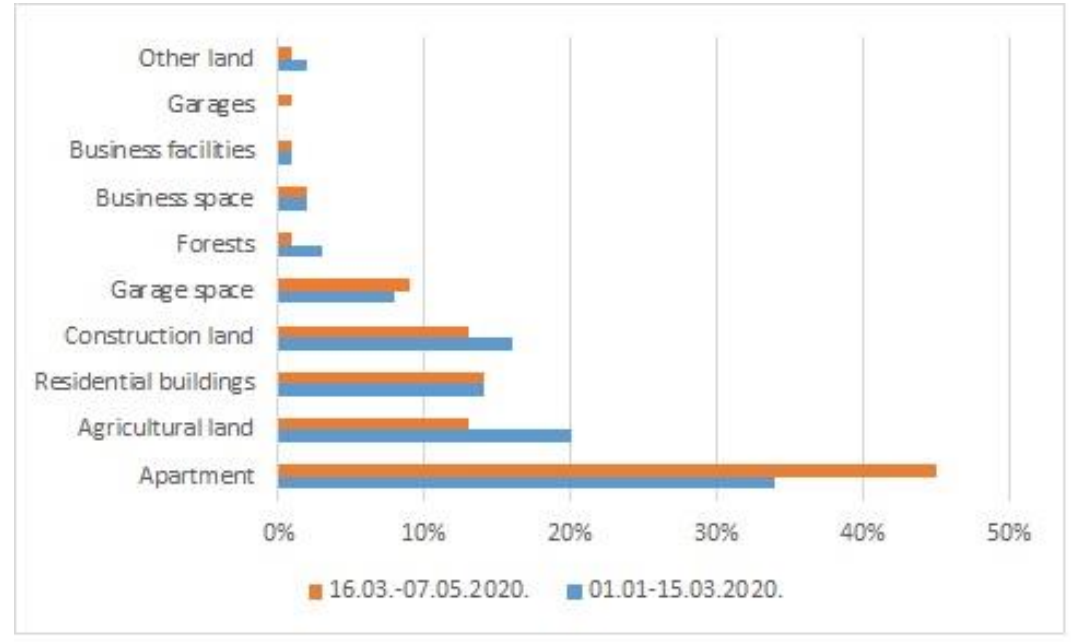

Figure 15: Registered sales by type of real estate

The cottages proved to be particularly attractive properties during the state of emergency, however their sales during the Covid-19 pandemic were at a similar level as for the same period last year. All indicators indicate that in the coming period there will be an increase in demand when it comes to these properties. The first indicators after the state of emergency indicate that there is a noticeable increase in sales of these properties. In May, 161 cottages were sold compared to 91 that were sold in May of the previous year, which is $44 \%$ more. These numbers lead us to the conclusion that in the coming period there will be an increase in demand when it comes to these properties.

\subsubsection{Share of Participants in the Real Estate Market}

In order to fully understand the situation on the market, the share of market participants was analyzed, ie. individuals, investors and other legal entities. Analyzing their market share before and during the state of emergency, it can be seen that their percentage share has not changed (Republic Geodetic Authority, 2020) (Figure 16).

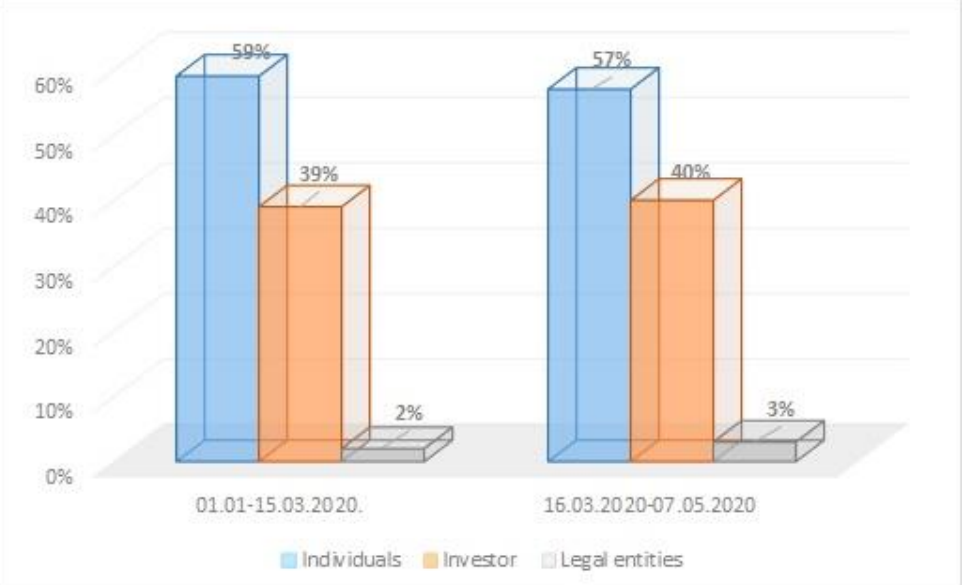

Figure 16: Percentage of registered sales of apartments by type of legal business 


\section{CONCLUSION}

During the Covid-19 pandemic, there were changes in the way businesses operate around the world. Market participants have focused their business on the implementation of egovernment services. Work from home was introduced. Organizations that perform service activities, and which were not vital to the lives of the residents, have completely ceased operations. The impact of Covid-19 was also felt in the real estate market development projects. Market participants tried to stay active during the pandemic by applying online real estate browsing technologies.

Based on these facts, the authors in this paper wanted to answer the question of how much the Covid-19 pandemic will harm a country's economy and real estate market development projects. In order to gain a global picture of the real estate market, an overview of the real estate market in China, the USA, some European countries and the Republic of Serbia was made. Regardless of the fact that the virus pandemic appeared in different time periods in the world, it can be concluded that the indicators of changes in the real estate market indicate the same trend of behavior. In China, the appearance of Covid-19 led to a drop in real estate sales by $90 \%$ compared to the same period in 2019. The U.S. real estate market is only now experiencing a drop in sales, and statistics indicate a 15\% drop in sales in April. In the analyzed European countries such as Great Britain and Italy, real estate sales fell by $70 \%$. The same situation was shown on the real estate market in the Republic of Serbia, where the data of the Department for Real Estate Appraisal and Management at the Republic Geodetic Authority were analyzed.

The real estate market development project is expected to recover considerably in areas that have been hit hard by Covid-19. However, open questions remain: What changes will follow in the real estate market as a result of the Covid-19 virus? Will the price of real estate decrease due to reduced demand? Will the population focus on buying real estate in rural areas? Will the demand for housing increase due to the end of the pandemic, and will life return to the conditions that were valid even before the virus appeared? Do architects shift to post-covid real estate remodeling when envisioning a new definition of "home"?

These are all open questions that will be answered in the future, and for now, the conclusion remains that the appearance of Covid-19 has influenced changes in the real estate market development projects. Its influence will certainly contribute to the real estate market shifting more to the use of modern technologies.

\section{REFERENCES}

Bethune, A. Z., \& Korinek, A. (2020). Covid19 Infection Externalities: Trading Off Lives vs. Livelihoods. The National Bureau of Economic Research, NBER Working Paper No. 27009, doi: 10.3386/w27009

Caldwell, F., Baum, C. H., \& Di Maio, A. (2000). What Is E-Government? Gartner's Definitions. available: https://www.gartner.com/en/documents/3 08454/what-is-e-government-gartner-sdefinitions

China Merchants Securities. (2020). Available at: www.newone.com.cn/en

Đoković, M. (2009). Osnova prometa nepokretnosti, ISBN 978-86-912463-0-3, Beograd

Forbes. (2020). What will America's housing marke look like after the Coronavirus pandemic ends? Here's what 5 top producing real estate adents had to say. Available at: https://www.forbes.com/sites/petertaylor/ 2020/04/12/what-will-americas-housingmarket-look-like-after-the-coronaviruspandemic-ends-heres-what-5-topproducing-real-estate-agents-had-tosay/\#894b7cb49525

Gis and data. (2020). Available at: https://gisanddata.maps.arcgis.com/apps/ opsdashboard/index.html\#/bda7594740fd 40299423467b48e9ecf6).

Gross, M., \& Lin, C. (2020). Comparison of real estate management system in China and Poland. Real Estate Management and Valuation. 28(1), pp. 13-27. doi: https://doi.org/10.2478/remav-2020-0002

Jovanović-Milenković, M., Radojičić, Z., Milenković, D., \& Vukmirović, D. 
(2009). Applying electronic documents in development of the healthcare information system in the Republic of Serbia. Computer Science and Information Systems. 6(2), pp. 111-126, doi: 10.2298/CSIS0902111J

Keramati, A., Behmanesh, I., \& Noori, H. (2018). Assessing the impact of readiness factors on e-government outcomes: An empirical investigation. Information Development. 34(3), pp. 222-241, https://doi.org/10.1177/02666669166856 03

Lisi, G. (2019). The search and matching process in the housing market: Explaining the phenomenon of the house price dispersion. Journal of European Real Estate Research. 12(3), pp. 380-391. doi: 10.1108/JERER-02-2019-0003

McKibbin, W., \& Roshen, F. (2020). The global macroeconomic impacts of covid19: Seven scenarios. Available at: www.brookings.edu/research/ the-globalmacroeconomic-impacts-of-covid-19seven-scenarios/

Naled. (2019). Analiza stanja elektronske uprave u Republici Srbiji: rezultati konsultativnog procesa. Beograd

National Association of Realtors. (2020). Available at: www.nar.realtor

National Bureau of Statistics of China. (2020). Available at: http://www.stats.gov.cn/english/

Nomisma si trova a Bologna. (2020). L'andamento del mercato immobiliare italiano nei dati del 1 Rapporto 2020 di Nomisma. Available at: https://www.nomisma.it/andamento-delmercato-immobiliare-italiano/.
Norada Real Estate Investments. (2020). Available at: www.noradarealestate.com/blog/housingmarket-predictions/

Pagourtzi, E., Assimakopoulos, V., Hatzichristos, T., \& French, N. (2003). Real estate appraisal: a review of valuation methods. Journal of Property Investment \& Finance. 21(4), pp. 383401, doi: 10.1108/14635780310483656

Pere. (2020). available:

https://www.perenews.com/changes-tochinas-real-estate-market-areaccelerating/)

Pickford, J. (2020). Coronavirus fears hit UK property market as viewings dry up. Available at: https://www.ft.com/content/e30ccb846799-11ea-800d-da70cff6e4d3

Radenković, B., Despotović-Zrakić, M., Bogdanović, Z., Barać, D., Labus, A., \& Bojović, Ž. (2017). Internet inteligentnih uređaja - Prvi udžbenik na srpskom jeziku izoblasti Internet of things. Fakultet organizacionih nauka. ISBN: 978-867680-304-0

Real Capital Analytics. (2020). Available at: www.rcanalytics.com/

Republički geodetski zavod. (2020). Izveštaj Odeljenja za procenu i vođenje nepokretnosti na tržištu nepokretnosti

Tahirović, T., Naumović, T., Živojinović, L., Bogdanović, Z., \& Despotović-Zrakić, M. (2018). Designing augmented reality services for e-business: a project management perspective. European Project Management Journal. 8(2), pp. 916, doi: 10.18485/epmj.2018.8.2.2

Zoopla Estimates. (2020). Available at: www.zoopla.co.uk 